\title{
REGIONALNA KOMPONENTA PRI NAČRTOVANJU RAZVOJA PODEŽELJA
}

\author{
Anton Prosen \\ Oddelek za geodezijo, Fakulteta za gradbeništvo in geodezijo, \\ Jamova 2, SI-I000 Ljubljana \\ e-mail: aprosen@fgg.uni-lj.si \\ Izvirni znanstveni članek \\ COBISS 1.01
}

\section{Izvleček}

V prispevku so predstavljene osnovne značilnosti regionalne komponente pri načrtovanju razvoja podeželja. Urejanje podeželskega prostora in razvoj teh območij se je začel v srednjeevropskih državah pred približno tridesetimi leti predvsem zaradi velikih strukturnih sprememb v posameznih dejavnostih. V začetku devetdesetih let prejšnjega stoletja je tudi Slovenija poskušala razviti metode urejanja in razvoja podeželja, žal pa smo ostali bolj pri poskusih. Uvajanje regionalne komponente je nujnost, saj razvoj ne more biti uspešen zgolj na manjši prostorski enoti.

Ključne besede: urejanje prostora, razvoj podeželja, regija, regionalni razvoj

\section{REGIONAL ASPECT OF RURAL DEVELOPMENT PLANNING}

\begin{abstract}
The paper discusses the basic features of the regional aspect of rural development planning. Management of rural areas and development of rural areas in the Central European countries started approximately thirty years ago mainly due to considerable structural changes in separate sectors. In the beginning of the 1990's, Slovenia also attempted to develop methods of rural management and development, however, these attempts remained more or less in the start-up phase. The implementation of the regional aspect has become a necessity, since rural development cannot be successful only in small spatial units.
\end{abstract}

Key words: spatial management, rural development, region, regional development 


\section{UVOD}

Slovenija, danes kot članica Evropske unije (EU), še vedno sodi v t. i. tranzicijske države srednje in vzhodne Evrope. V zadnjem poldrugem desetletju je doživela velike spremembe, tako na političnem, socialnem in gospodarskem področju. Te spremembe pa prinašajo tudi vse večje regionalne razlike, kar se odraža predvsem na podeželju. To nas vendarle sili, da intenzivneje razmišljamo o spremenjenih metodah dela na uveljavitvi regionalne politike Slovenije, ki bo odražala načine in pristope drugih članic EU.

Z odločitvami, da se vključimo v procese združevanja Evrope, smo morali intenzivno pristopiti k prevzemanju pravnega reda EU za vsa področja. Velika naloga, ki jo je Slovenija bolj ali manj uspešno izpeljala. Ne le vstopanje Slovenije v EU in evropske integracije nasploh, temveč globalizacija gospodarskih, političnih in kulturnih odnosov ter prehod $\mathrm{v}$ informacijsko družbo prinašajo tudi slovenskemu podeželskemu prostoru hitre in nezadržne spremembe. Za spremljanje vseh procesov v prostoru se v Sloveniji v zadnjih desetih letih trudimo, da bi prevzeli in uveljavili usmeritve, ki izhajajo iz AGENDE 2000, drugih aktov EU, dokumentov ZN, sveta Evrope idr. V tem prispevku želimo na kratko prikazati ta prizadevanja po čimprejšnji uveljavitvi metod in ukrepov EU za področje urejanja in razvoja podeželja ob upoštevanju regionalne komponente. Prikazana so prostorsko relevantna opravila, ki jih prištevamo k področju razvoja podeželja.

\section{ZNAČILNOSTI SLOVENSKEGA PODEŽELJA IN KMETIJSTVA}

S svojo velikostjo $20.256 \mathrm{~km}^{2}$ in 1.964 .036 prebivalci je Slovenija pravzaprav ena manjših držav v Evropi. Kljub svoji majhnosti pa predstavlja tako v pokrajinskem kot poselitvenem smislu posebnost, ki se kaže v raznoliki krajini in množici malih naselij. Slovenci živimo v 5.997 naseljih, ki so več ali manj mala naselja oz. vasi; 5961 je majhnih naselij, od katerih jih ima kar četrtina manj kot 50 prebivalcev. Samo $90 \%$ naselij ima do 500 prebivalcev. Slovenija ima 51 mest, od tega jih ima le 7 več kot 20.000 prebivalcev. Tako danes v urbanih naseljih živi 943.516 prebivalcev ali $48 \%$, v podeželskih naseljih pa 1.020 .520 ali $52 \%$. Posledica takega poselitvenega razvoja se odraža v izjemni arhitekturni in kulturni dediščini, ki je prisotna v številnih naseljih (Strategija, 2003). To pa zahteva od stroke kot tudi politike, da so posegi v prostor strokovno premišljeni.

Hitra deagrarizacija v celotnem obdobju po drugi svetovni vojni je vplivala na to, da se nekatera območja Slovenije, zlasti obmejna in hribovita, praznijo. Območja praznjenja obsegajo že skoraj 40 \% površine slovenske države. Prebivalstvo na teh območjih zaradi slabe starostne strukture ne more več vzdrževati ne lokalne infrastrukture ne kulturne krajine.

Vloga kmetijstva v okviru celotnega gospodarskega razvoja se iz leta v leto znižuje, tako je delež kmetijstva v slovenskem bruto domačem proizvodu v letu 2000 znašal okoli $3 \%$, v njem pa je zaposlenih približno $5 \%$ aktivnega prebivalstva (Erjavec, 2003). Kljub majhni gospodarski vlogi ostaja kmetijstvo pomemben faktor razvoja in socialne stabilnosti podeželskega prostora. Slovenija ima razmeroma neugodne naravne razmere za kmetijstvo. 
Zemljišča, primerna za kmetijstvo, so omejena, saj gozdovi pokrivajo približno $60 \%$ ozemlja. Kmetijske površine naj bi po najnovejših podatkih obsegale le še približno 30 \% ozemlja države. Okoli 75 \% kmetijskih zemljišč je na območjih z neugodnimi razmerami za kmetijsko dejavnost, kar omejuje izbor proizvodnih usmeritev ter znižuje produktivnost in povečuje proizvodne stroške. V strukturi kmetijske zemlje prevladuje trajno travinje (okoli 60 \%).

Pomembna ovira za večjo učinkovitost in gospodarsko uspešnost kmetovanja je tudi razdrobljena posestna in parcelna struktura kmetijskih zemljišč v Sloveniji. Po podatkih popisa 2000 se v Sloveniji s kmetijstvom ukvarja 86.467 kmetijskih gospodarstev (v letu 2003 77.100). Večino predstavljajo družinske kmetije (99,8 \%) ki obdelujejo 94 \% vse kmetijske zemlje v uporabi. Preostalih $6 \%$ je v obdelavi praviloma večjih in s posestnega vidika bolj zaokroženih kmetijskih podjetij, družb in zadrug. Število kmetijskih gospodarstev se je od zadnjega popisa prebivalstva v letu 1991 (ki je bil hkrati tudi delni popis kmetijstva) zmanjšalo za več kot 25.000 ali za $23 \%$. V letu 2000 je kmetijsko gospodarstvo v povprečju obdelovalo 5,6 hektarov kmetijske zemlje (v letu 2003 pa 6,2 ha), kar je 0,9 hektarov ali $19 \%$ več kot v letu 1991 (4,7 ha na gospodarstvo). Velikostna struktura kmetijskih gospodarstev kljub razmeroma hitremu trendu koncentracije posesti, ki smo mu priča v zadnjem desetletju, ostaja zelo neugodna. Največ kmetijskih gospodarstev je v velikostnem razredu z 2 do 5 ha kmetijske zemlje v uporabi, drugo najpomembnejšo skupino pa predstavljajo kmetijska gospodarstva $\mathrm{s}$ 5 do 10 ha kmetijske zemlje. Ti dve skupini še vedno pomenita jedro kmetijske strukture $\mathrm{v}$ Sloveniji, saj zajemata več kot $60 \%$ vseh kmetijskih gospodarstev in več kot $50 \%$ kmetijskih zemljišč v uporabi. Več kot 20 ha kmetijskih zemljišč ima le okoli 1.700 kmetij. V Sloveniji prevladujejo mešane in dopolnilne kmetije, ki imajo v lasti preko 50 \% vse kmetijske zemlje. Velika je tudi parcelna razdrobljenost, ki jo ponazarja podatek, da se kmetijska pridelava izvaja na okoli 3,1 milijonih parcel (Resolucija, 2003) s povprečno velikostjo 0,40 ha.

Za Slovenijo je značilen tudi zelo hiter proces zmanjševanja obsega kmetijskih zemljišč. Trend gre v smer povečanja gozdnih površin (zaraščanje slabših kmetijskih zemljišč) in površin za urbanizacijo in infrastrukturo. Interes po zazidljivih zemljiščih na območjih najkakovostnejših kmetijskih zemljišč se je z ustanovitvijo novih občin in potreb po izgradnji infrastrukture v zadnjih letih močno povečal. Slovensko podeželje je po eni strani čedalje bolj urbanizirano, po drugi pa gre za praznjenje in degradacijo krajin.

\section{PLANIRANJE PODEŽELSKEGA PROSTORA}

V nadaljevanju si poglejmo, kako obravnavata podeželski prostor zakonodaja in praksa s področja prostorskega planiranja.

V obdobju po drugi svetovni vojni je bil v takratni državi Jugoslaviji poudarek na hitri industrializaciji in urbanizaciji prevladujoče agrarne družbe. Vsa zakonodaja in ukrepi so bili usmerjeni v ustvarjanje močnih urbanih centrov ter izgradnjo novih mest. Šele zakonodaja iz leta 1967 (Zakon o urbanističnem planiranju in Zakon o regionalnem prostorskem planiranju) je predpisovala za podeželski prostor »urbanistični red«, ki je bil namenjen urbanističnemu urejanju (vaških) naselij. Če se danes oziramo v to obdobje, ugotovimo, da smo morda z urbanističnimi redi sprožili vseobsežno samograditeljstvo (Prosen, 1987), saj je ob splošnem 
razvoju družbe in življenjskega standarda močno primanjkovalo stanovanj in stavbnih zemljišč v urbanih centrih. Tudi poznejša spremenjena zakonodaja je omogočila stanovanjsko in drugo izgradnjo na podeželju.

Zakonodaja iz leta 2003 na področju prostorskega in urbanističnega planiranja uveljavlja ukrepe za realizacijo načrtovanih prostorskih posegov, opremljanje zemljišč za gradnjo, reguliranje dejavnosti prostorskega načrtovanja ter vzpostavitev prostorskega informacijskega sistema. Vnovič se uveljavlja tri-nivojsko planiranje (država, regija, občina) in hierarhija planskih dokumentov, akti pa so strateški in operativni. Strateški so usmerjevalni akti, operativni ali izvedbeni akti določajo pogoje za rabo zemljišč (prostorski red občine) in gradnjo objektov (občinski lokacijski načrt). Za podeželski prostor bo poleg strateškega akta (strategija prostorskega razvoja občine in krajinskih zasnov) sprejet prostorski red občine in morda posamezni lokacijski načrti. Nova zakonodaja žal ni določila, kako bomo v Sloveniji nadaljevali s projekti prenove vasi in drugimi projekti za razvoj podeželja in urejanje zemljišč.

\section{KMETIJSTVO IN RAZVOJ PODEŽELJA}

Strukturne spremembe v družbi, še posebej pa v kmetijskem sektorju, se kažejo predvsem v hitri spremembi agrarne krajine in v vaseh (Weber, 2002), tu se koncentrira ob kmetijskih vse več nekmetijskih dejavnosti. Da ne bi strukturne spremembe ovirale razvoja kmetijstva na podeželju, se je kmetijski sektor kmalu po osamosvojitvi začel zavedati, da bo zato moral, po zgledu drugih evropskih držav, prevzeti določene naloge v zvezi z razvojem podeželja in kmetijstva. Temelji samostojne kmetijske politike v Sloveniji so bili postavljeni s sprejetjem Strategije razvoja slovenskega kmetijstva (1993), v kateri so opredeljeni najpomembnejši cilji kmetijske politike. S tem dokumentom je kmetijstvu poleg proizvodne funkcije priznana tudi pomembna vloga pri oblikovanju in ohranjanju kulturne krajine, zaščiti naravnih virov, varovanju okolja in razvoju podeželja.

Formalno je nove usmeritve v kmetijski politiki opredelil Program reforme kmetijske politike 1999-2002 (1998) in na tej podlagi sprejeti Program razvoja kmetijstva, živilstva, gozdarstva in ribištva 2000-2002. Z reformo je bil večji poudarek dan ukrepom kmetijske strukturne politike. Z opredelitvijo Slovenije za spodbujanje modela multifunkcionalne vloge kmetijstva je povezano priznavanje njegove vloge pri zagotavljanju ciljev širšega družbenega pomena (naravni viri, kulturna krajina, poseljenost). Novi programi in povečanje sredstev bi morali vsaj delno zaustavili nekatere negativne trende (zaraščanje, obremenitev okolja, depopulacija, propad tradicionalnih krajin), povezane s strukturnimi spremembami v kmetijstvu. Pomembno vlogo imajo podpore programom razvoja podeželja (prostorsko urejanje podeželja, ekonomska diverzifikacija podeželja, inovativni programi za razvoj gospodarstva na podeželju).

Strateški cilji kmetijske politike v Republiki Sloveniji so določeni v Zakonu o kmetijstvu (2000). Zakon določa, da so za uresničevanje gospodarske, prostorske, ekološke in socialne vloge kmetijstva ter njegovega sonaravnega razvoja pomembni naslednji cilji:

- $\quad$ stabilna pridelava kakovostne in čim cenejše hrane ter zagotavljanje prehranske varnosti; 
- $\quad$ ohranjanje poseljenosti podeželja in krajine;

- $\quad$ varstvo kmetijskih zemljišč pred onesnaženjem in nesmotrno rabo;

- trajno povečevanje konkurenčne sposobnosti kmetijstva;

- zagotavljanje primerne dohodkovne ravni kmetijskim gospodarstvom;

- uresničevanje načel varstva okolja in ohranjanja narave.

Celotna politika in smernice za razvoj kmetijstva in podeželja sloni na temeljnem dokumentu EU, to je Agendi 2000 (Schlagheck, 1999). Kmetijstvu kot gospodarski panogi tako tudi v Sloveniji pripisujemo nove naloge, in sicer: konkurenčnost, trajnost in večfunkcionalnost. Ob tem pa tudi produkcijsko, ekološko in družbeno funkcijo (Grabski-Kieron, 2002). Tako se približuje Slovenija ciljem razvoja podeželskega prostora in izvajanja skupne kmetijske politike EU.

Ker je razvoj podeželja razumeti kot kompleksno nalogo, ki vendarle ne mora biti koncentrirana samo na kmetijstvu, so posamezne države pristopile k reviziji tako zakonodaje kot programov, saj ugotavljajo, da je strukturno izboljšanje možno le s porajanjem lokalne in regionalne ustvarjene vrednosti. Prizadevati si moramo predvsem za kooperacijo med turizmom, obrtjo in storitvami. Za dosego tega je treba zgraditi mrežo, ki lahko izboljša koordinacijo med prostorsko relevantnimi politikami na različnih ravneh.

\section{UREJANJE ZEMLJIŠČ IN KOMASACIJA}

Kot že omenjeno, je v Sloveniji v posameznih predelih razdrobljenost in majhnost kmetij izredno kritična. Velikostna struktura in razdrobljenost posesti pa sta po mnenju agrarnih strokovnjakov dva od največjih agrarnopolitičnih problemov v Sloveniji (Kovačič, 1995). Zato smo v preteklosti poskušali ta problem bolj ali manj uspešno reševati z agrarnimi operacijami (melioracije, komasacije). Urejanje kmetijskega prostora s komasacijami in melioracijami v Sloveniji po drugi svetovni vojni lahko razdelimo na štiri obdobja (Kokolj-Prošek, 2001), nobeno pa ni uvedlo kompleksnega urejanja prostora.

Podatki Ministrstva za kmetijstvo, gozdarstvo in prehrano kažejo, da je bilo v obdobju 1976-1980 izvedenih komasacij na 782 ha, v obdobju 1981-1985 na 22.735 ha in v obdobju 1986-1990 na 26.785 ha. Skupaj v obdobju do leta 1990 na 54.344 ha. Kot je razvidno iz navedenih podatkov, se pričenja intenzivnejše obdobje za izvajanje komasacij v Sloveniji po letu 1973, ko je bil sprejet zakon o kmetijskih zemljiščih. Cilji takratnih komasacij so bili usmerjeni v povečanje družbene lastnine na zemljiščih, ne pa v večanje posameznih družinskih kmetij, zato se je tudi zakon o kmetijskih zemljiščih večkrat popravljal in dopolnjeval.

V letu 1990 je takratna Skupščina RS sprejela sklep o moratoriju nad izvajanjem melioracij in neposredno tudi komasacij, saj je bil običaj, da je postopku melioracije sledil postopek komasacije. Prepoved se je nanašala predvsem na hidromelioracije in posege v vodni svet, porajala pa se je zahteva po sanacijah že izvedenih del (renaturacije). V poznejših letih je bilo tudi ugotovljeno, da mnoge komasacije iz preteklih obdobij niso bile dokončane (125 območij) in da so bili z izvedbo del lastniki zemljišč nezadovoljni, saj so smatrali, da so bili prisiljeni v komasacijske postopke. Leta 1994 je bil izdelan Program sanacije komasacij (Kokolj Prošek, 2001). 
Leta 1996 je bil sprejet nov Zakon o kmetijskih zemljiščih, ta je med drugim predvidel večjo stopnjo demokratičnosti pri postopkih komasacije. V zadnjih letih se ponovno pojavljajo potrebe po novih komasacijah, predvsem kot posledica zaključevanja denacionalizacijskih postopkov, večjih posegov v prostor (AC, železnice itn.) kot tudi želja kmetov po združevanju razdrobljene posesti v večje parcele.

Napake in pomanjkljivosti se bodo morda postopoma odpravile, izvedba del je uspešnejša kot $\mathrm{v}$ preteklosti in vidni so že novi uspehi. Večfunkcionalnost kmetijstva in podeželja narekuje, da je treba prostor načrtovati tako, da je sposoben za opravljanje posameznih funkcij, kot npr. rekreacije v podeželskem prostoru itn. Postopke bo treba še bolj prilagoditi metodam za trajnostno urejanje podeželskega prostora in spoštovanje kulturne in naravne dediščine.

Ta trenutek je stanje v Sloveniji kot tudi v drugih tranzicijskih državah na področju zemljiške strukture izredno nezavidljivo (Dale, 2002). Postopki komasacije naj bi postopoma postali vodilni za izboljšanje agrarne strukture, razvoj podeželja, izgradnjo infrastrukture, prenovo in razvoj vasi itn. Ob tem pa bi morali upoštevati potrebe po prostoru tako širše lokalne skupnost kot posameznih zahtev po prostoru, ki izhajajo iz regionalnih razvojnih projektov (urejanje infrstrukture, melioracijska dela, razvoj turizma, obrti itn.).

\section{PRIZADEVANJA ZA PRENOVO VASI V SLOVENIJI}

Že v osemdesetih letih smo začeli strokovnjaki opozarjati na napake, ki se odražajo v podeželskem prostoru, na vlogo in pomen tega prostora in na metode, $\mathrm{s}$ katerimi rešujejo probleme kmetijstva in podeželja v drugih državah, predvsem v ZR Nemčiji. Uspešnost dela na področju prenove vasi, komasacij in urejanja zemljišč v ZRN je bila podlaga za ustanovitev sektorja za strukturno politiko in razvoj podeželja na Ministrstvu za kmetijstvo, gozdarstvo in prehrano. Ta sektor je razvil posebne projekte za razvoj podeželja in prenovo vasi, imenovane Celostni razvoj podeželja in obnova vasi (CRPOV, 2002).

Programi prenove vasi in razvojni programi ter programi za ohranjanje podeželske dediščine so namenjeni obnovi in ohranjanja kulturne in arhitekturne dediščine, izboljšanju kvalitete življenja in dela lokalnih prebivalcev in povečanju potenciala za razvoj alternativnih in dopolnilnih gospodarskih dejavnosti na podeželju. S temi projekti naj bi se izboljšala ekonomska, socialna in ekološka situacija na podeželju.

Projekti so bili pomemben del kmetijske strukturne politike razvoja podeželja. Tako po vsebinski kot metodološki plati so projekti, čeprav so bili že uveljavljeni, še v razvojni fazi. Glede na to, da vodi in financira te projekte kmetijski sektor, bi pričakovali, da bo ta sektor $\mathrm{v}$ okviru teh načrtov uveljavil svoje zahteve po razvoju v prostoru (ureditev in preselitev posameznih kmetij, ureditev prometa za kmetijske stroje, zaščita pred imisijami iz kmetijskih obratov itn.). Kmetijstvo ni razvilo ustreznega razvojnega planiranja za svoj sektor, po zgledu agrarnega strukturnega razvojnega planiranja v ZR Nemčiji. Nerešene so morda tudi pristojnosti med ministrstvi itn. V Sloveniji tudi ni ustreznih služb, ki bi koordinirale in vodile dela na terenu, po zgledu direkcij za razvoj podeželja v ZRN (Magel, 1997). Precejšnje je pomanjkanje specializiranih strokovnjakov v posameznih strokah (arhitektura, geodezija, kmetijstvo idr.), ki bi sodelovali pri teh projektih in ki bi bili sposobni razviti ustrezne metode dela, podobne že uveljavljenim v ZR Nemčiji in drugod (Prosen, 2000). 
Ker predstavljajo načrti za razvoj podeželja in prenove vasi tudi načrte za realizacijo ukrepov iz različnih planskih ravni (država, regija, občina), je velikokrat težko uresničiti te cilje, saj so nekateri planski akti pomanjkljivi in ni jasno, kaj bi morali vsebovati načrti za prenovo vasi, katere pomembne funkcije naj bi razvijali v posamezni vasi, saj je ravno v teh projektih manjkala regionalna komponenta. Manjkali so tudi ukrepi urejanja zemljišč in s tem možnosti za realizacijo načrtov. V skladu z dosedanjimi izkušnjami in prenosom izkušenj uveljavljenih načinov iz tujine (Attenberger, Magel, 1989; Magel, 2002) je nujno treba razviti ustrezno metodologijo nastajanja takih načrtov, ki zajema tudi sektorsko planiranje. Te dejavnosti so: bivanje, kmetijstvo, obrt, promet, infrastruktura, podoba naselja, prosti čas in razvedrilo, kultura na vasi, delovna mesta itn.

Kljub pomanjkljivostim posamezne uspešne realizacije kažejo, da bodo z ustreznimi popravki in korekturami ti projekti v bodoče uspešni ob sodelovanju predvsem občin in prebivalcev vasi, ki se obnavljajo. Ne nazadnje pa bo te projekte treba podpreti tako zakonsko kot tudi finančno.

Vključitev Slovenije v evropsko integracijo naj bi pripomogla, da se tako evropska zakonodaja kot strokovne metode dela na področju prenove vasi in razvoja podeželja hitreje uveljavijo $\mathrm{v}$ prid trajnostnega razvoja in jačanja demokratičnih procesov na vseh ravneh, posebno pa na lokalni ravni ob upoštevanju delitev funkcij med posameznimi naselji ob upoštevanju zakonitosti regionalnega razvoja (Vrišer, 1979).

\section{ZAKLJUČEK}

Slovenija se je že pred dobrim desetletjem odločila, da razvije lastne projekte za razvoj podeželskega prostora in razvoj kmetijstva ter za postopni prehod v izvajanje skupne kmetijske politike EU. Izkušnje kažejo, da ne bomo imeli večjih težav pri izvajanju direktive EU št. 1257/1999 in ukrepov, ki so konkretizirani v 33. členu EU VO 1257 v poglavju IX »Podpora prilagajanju in razvoj podeželskih območij«(Thomas, 2002). Danes so npr. komasacije v Evropi vse bolj sredstvo za trajnostno urejanje prostora na lokalni in regionalni ravni (Münchenska deklaracija, 2002) s ciljem izboljšanja agrarne strukture in razvoja podeželja. Ti projekti pa vključujejo področje urejanja zemljišč, razvoja podeželja in zemljiškega managementa (Magel, 2003), kar omogoča realizacijo posameznih tako sektorskih kot integralnih načrtov.

Politične ali strokovne odločitve na prostor vplivajo direktno ali indirektno. Da se izognemo posameznim parcialnim odločitvam, je treba pričeti graditi ustrezno kooperativno sodelovanje, da se lahko izboljšajo prostorsko relevantne politike. Številne sektorske in stvarne politike vplivajo na podeželski prostor: kmetijstvo in gozdarstvo, turizem, varstvo narave in kulturne dediščine kot tudi prostorsko načrtovanje, promet, financiranje itn. $\mathrm{K}$ temu lahko dodamo še regulacije lokalnih predpisov. Brez upoštevanja kmetijstva in gozdarstva, ki po deležu vendarle zaseda največji del prostora, se razvoja podeželskega prostora ne more doseči. Istočasno pa ima kmetijstvo občutek, da mora tudi samo spodbujati neko dinamiko razvoja, kar je v skladu z njeno večfunkcionalnostjo, ki jo podpira predvsem skupna politika razvoja kmetijstva in podeželja v EU. Mnogi projekti pa se lahko realizirajo, če je prostorska enota, v kateri obravnavamo neko problematiko, širše zasnovana problemska regija (Kušar, 2004), 
ki ponavadi zajema več občin, ki jih problematika tangira. Kljub politični volji v Sloveniji še ni zaživela endogena regionalna politika (Markeš, 1998) in razvojne spodbude, saj se prebivalstveno podeželje še vedno prazni (Plut, 1998). Tu nas čaka še veliko strokovnega dela in predvsem politične volje oz. političnega konsenza.

$\mathrm{Z}$ medobčinsko kooperacijo dosegamo konkretne cilje, ki zadevajo posamezno območje, pomembni pa so še našteti cilji (Klaus, 2003), ki jih ob tem dosežemo:

- povečanje storilnost posamezne občine,

- izboljšanje posameznih ukrepov,

- zmanjšanje stroškov,

- zmanjševanje tveganj,

- pridobivanje strateške moči,

- izgradnja regionalne identitete,

- zmanjševanje konkurence,

- poskus novih zaposlitvenih možnosti,

- zmanjševanje točkovnega (parcialnega) planiranja,

- skupno nastopanje nasproti tretjim,

- boljše izkoriščanje (skupne) infrastrukture,

- krepitev inovacij in

- boljše vodenje investicij.

Za uresničitev ciljev in ukrepov za trajnostni razvoj podeželja (Novak, 2000) bo potrebna politična volja na različnih ravneh (regija, občina, vas). Za uresničevanje zastavljene politike integralnega razvoja podeželskega prostora je med drugim treba razvijati tudi instrumente regionalnega razvoja, zemljiškega menedžmenta itn. Le ti naj bi temeljili na sočasnem izboljševanjem lastninsko posestne strukture $\mathrm{v}$ kmetijskem pridelovalnem prostoru v povezavi z razvojem in preoblikovanjem vaških naselij, pridobivanjem potrebnih površine za rekreacijo, ekoloških tamponskih con ipd.

\section{Literatura in viri}

CRPOV, 2002, Celostni razvoj podeželja in obnova vasi CRPOV 1990-2002. J. Kokolj Prošek (urednik), Ministrstvo za kmetijstvo, gozdarstvo in prehrano, Ljubljana.

Dale, P., 2002, A New Bone of Contention. Geoinformatics, in June 2002.

Erjavec, E., 2003, Sloweniens Landwirtschaft und die Europäische Union. Wien, Ländlicher Raum, Nr. 4, S. $2-8$.

Grabski-Kieron, U., 2002, Funktionswandel der Landwirtschaft - Neue Impulse für die ländliche Raumentwicklung? Raumordnung und landwirtschaftlicher Strukturwandel (Hrsg. Gerlind Weber), IRUB, Wien.

Klaus, M., 2003, Nachhaltigkeit durch Landentwicklung. Stand und Perspektiven für eine nachhaltige Entwicklung. TU München, Lehrstuhl für Bodenordnung und Landentwicklung.

Kokolj Prošek, J., 2001, Zemljiške operacije, izboljšanje posestne strukture ter priprava ustrezne zakonodaje. V: Posestna sestava in kmetijska politika. XVI. tradicionalni posvet 
Kmetijske svetovalne službe Slovenije, Bled 26.-27. november 2001, Zbornik posveta. Kmetijsko gozdarska zbornica Slovenije.

Kovačič, M.. 1995, Socio-ekonomska in velikostna struktura kmetij v Sloveniji v obdobju 1981-1991. Ljubljana, Biotehniška fakulteta.

Kušar, S., 2004, Razvrščanje v skupine z omejitvami kot metoda regionalizacije. Urbani izziv, letnik 15, št. 2/04, str. 87-92.

Magel, H., Attenberger, J., 1989, Das Bayerische Dorferneuerungsprogram. - Hrsg. HansSeidel-Stiftung. München, Broschüre 9.

Magel, H., 1997, Strategisches Konzept „Ländliche Entwicklung 2000++ in Slowenien”. München im März 1997 (nepublicirano).

Magel, H., 2002, 20 Jahre Bayerisches Dorferneuerungsprogramm: Ein- und Aussichten. Sociologija sela, Zagreb, 40 (2002) 155/156.

Magel, H., 2003, Landmanagement - Die neue Herausforderung an Bodenordnung und Landentwicklung. Flächmanagement und Bodenordnung, 1/2003.

Markeš, M., 1998, Vloga kmetijstva v Triglavskem narodnem parku. V Kmetijstvo in okolje (zbornik posveta), Bled, 12.-13. 3. 1998, Kmetijski inštitut Slovenije, str. 91-96.

Novak, J., 2000, Pomen regionalnega razvoja pri urejanju podeželskega prostora : diplomska naloga. Ljubljana: Fakulteta za gradbeništvo in geodezijo, Oddelek za geodezijo.

Plut, D., 1998, Slovensko kmetijstvo in regionalni razvoj. V Kmetijstvo in okolje (zbornik posveta), Bled, 12.-13. 3. 1998, Kmetijski inštitut Slovenije, str. 29-36.

Program reforme kmetijske politike 1999-2002, 1998. Ministrstvo za kmetijstvo, gozdarstvo in prehrano, Ljubljana.

Prosen, A., 2000, Dorferneuerung in Slowenien - von der Idee bis zum Versuch der Realisierung. Zeitschrift für Kulturtechnik und Landentwicklung, Berlin, 41 (2000).

Prosen, A., 1987, Planiranje podeželskega prostora. Fakulteta za gradbeništvo in geodezijo, Ljubljana.

Resolucija, 2003, Resolucija o strateških ciljih in ukrepih na področju razvoja kmetijstva v Sloveniji, Ministrstvo za kmetijstvo, gozdarstvo in prehrano, Ljubljana.

Strategija razvoja slovenskega kmetijstva, 1993. Ministrstvo za kmetijstvo, gozdarstvo in prehrano, Ljubljana.

Schlagheck, H., 1999, Integrierte Konzepte für eine nachhaltige Entwicklung ländlicher Räume und ihrer Dörfer in Deutschland. Zukunft im ländlichen Raum gemeinsam gestalten (1999), Schriftenreihe des Bundesministeriums für Ernährung, Landwirtschaft und Forsten, Reihe B, Flurbereinigung, Landwirtschaftsverlag GmbH, Muenster-Hiltrup.

Strategija, 2003, Strategija prostorskega razvoja Slovenije. Ministrstvo za okolje in prostor, Ljubljana.

The Munich Statement, 2002, The Munich Statement on land consolidation as a tool for rural development in CEE/CIS countries. V: Babete Wehrmann, Michael Klaus i Martina Strasser (edit.): Documentation of the international symposium on «Land fragmentation and land consolidation in CEEC: A gate towards sustainable rural development in the 
new millennium», Munich, 25-28 February 2002. Printversion of the hard-copy: http:// www.landentwicklung-muenchen.de/.

Thomas, J., 2002, Ländliche Entwicklung - nationale Strukturförderung im europäischen Kontex. ZFV, št. 2/2002.

Vrišer, I., 1978, Regionalno planiranje. Ljubljana, Mladinska knjiga.

Weber, G., 2002, Die Steuerung der Umnutzung landwirtschaftlicher Gebäude - eine Herausforderung für die Raumplanung. Raumordnung und landwirtschaftlicher Strukturwandel (Hrsg. Gerlind Weber), IRUB, Wien.

\section{REGIONAL ASPECT OF RURAL DEVELOPMENT PLANNING}

\section{Summary}

Slovenia, today already as an EU member, is still considered as one of the transitional countries of Central and Eastern Europe. In the last fifteen years Slovenia has undergone many changes in political, social and economic areas. These changes have resulted in larger regional differences, which have become evident mostly in rural areas. This has forced us to direct our attention to changed methods of work in implementing the regional policy in Slovenia, which would reflect the ways and approaches of other EU members. Not only the accession of Slovenia into the EU and European integrations in general, but also globalization of economic, political and cultural relationships and the transition into the information society have brought fast and irretrievable changes to the Slovenian rural environment.

Slovenia is one of the smallest countries in Europe. Despite its size, in terms of its landscape features and settlement it represents some particularities that reflect in its diverse landscape and many small settlements. The Slovenians live in 5997 settlements, which are more or less small settlements or villages; thus out of 5961 small settlements a quarter has less than 50 inhabitants. Only $90 \%$ of settlements have up to 500 inhabitants. Slovenia has 51 towns, out of which 7 have more than 20,000 residents. Hence, in urban settlements today there are 943,516 inhabitants or $48 \%$, and in rural settlements $1,020,520$ or $52 \%$. The fast deagrarization in the period after World War II has resulted in the depopulation of some areas in Slovenia, especially in border areas and in hilly and mountainous areas. These regions include almost $40 \%$ of the Slovenian territory.

The role of agriculture within the economic development has been reducing from one year to the next, thus the share of agriculture in Slovenian gross domestic product in 2000 was around $3 \%$, and it employed approximately $5 \%$ of active population. Despite its smaller economic role, agriculture has remained an important factor of development and social stability of the rural space. An important obstacle to a higher efficiency and economic success of agriculture is also the dispersed land structure of agricultural land in Slovenia and adverse natural conditions for agriculture.

In Slovenia, legislation in the field of spatial and urban planning does not lay down the ways of continuing with the projects of village renewal and other projects of rural development and land management, thus attempts have been made to develop methods of work that will 
be comparable to those in other European countries. By introducing quality projects, one will have to put a stop to some negative trends, such as overgrown land, environmental strains, depopulation, disapperance of the traditional landscape. Preservation of agricultural activities, as a method of keeping and shaping the traditional landscape has become growingly important. The growth of rural lands is increasingly understood as a complex task, which cannot rely only on agricultural development, hence, the structural improvement is possible only with the emergence of locally and regionally produced development. In this sense, efforts have been made in Slovenia towards a co-operation between tourism, crafts and services.

Important to the rural development are the programs of village renewal, developmental programs, and programs for protection of rural heritage, which are oriented towards renewal and protection of cultural and architectural heritage, improved quality of life and work of local inhabitants and increased potential for development of alternative and supplementary economic activities in rural areas. These projects should improve the economic, social and ecological situation in the rural areas. They represent an important part of agricultural structural policy of rural development. However, in terms of contents and methodology these projects, eventhough being implemented, are still in their developmental phase. The inclusion of Slovenia in European integrations should have contributed to a faster implementation of European legislation and professional methods with a view of sustainable development and empowered democratic processes at all levels, but especially at the local level, taking into account the division of functions among settlements and with consideration of rules of spatial development.

In Slovenia, despite the political will being present, an endogeneous regional policy and developmental initiatives have not been realized yet, due to the depopulation of the rural areas. Thus, much professional work and especially political will and the need of political consensus lies ahead. 